\title{
SPECIFIC G PROTEINS MEDIATE ENDOTHELIN INDUCED CONTRACTION
}

\author{
Khalil N. Bitar, Stephanie Stein and Geneva M. Omann \\ University of Michigan Medical School, Ann Arbor, MI 48109-0658 \\ (Received in final form April 20, 1992)

\section{Summary}

Endothelin is a potent vasoconstrictor peptide which has recently been localized in the gastrointestinal tract. We have investigated the transmembrane signaling properties of endothelin in isolated smooth muscle cells of the rabbit rectosigmoid. Endothelin induced a dose dependent contraction of smooth muscle cells in a range of $10^{-10}$ to $10^{-6} \mathrm{M}$. In normal buffer, contraction peaked at $30 \mathrm{sec}$ and was sustained for up to $8 \mathrm{~min}$. Incubation in $0 \mathrm{Ca} / 2 \mathrm{mM}$ EGTA abolished the sustained contraction induced by endothelin, but had no effect on the initial transient contraction. Preincubation of saponin treated cells with $G$ protein antisera had no effect on control cell length. Preincubation of saponin treated isolated smooth muscle cells with specific $G$ protein antisera (rabbit antisera) for Goo or Gs for 60 minutes did not inhibit contraction induced by endothelin. Preincubation with an antiserum to $\mathrm{Gi}_{3} \alpha$ inhibited the initial transient contraction induced by endothelin and preincubation with an antiserum to $\mathrm{Gi}_{1-2} \alpha$ inhibited the sustained phase of the endothelin induced contraction. Our data indicate that: 1) Endothelin induces a direct sustained contraction of smooth cells from the rectosigmoid; 2) The transmembrane signalling of endothelin is through two specific GTP binding components that are Gia, one for the initial transient contraction, and the other for the sustained phase of the contraction.

Endothelins are a newly described peptide family consisting of three peptides (ET-1,ET-2,ET-3) which are the most potent vasoconstrictive peptides known $(1,2,3)$. The vasoconstrictive effects of ET-1 are long-lasting, so that a single small injection into the circulation of a rat increases the blood pressure for an hour or more.

Two distinct receptors for endothelin have been described. Those receptors probably serve different functions. Each of the receptors belongs to the family of rhodopsin like receptors, with seven transmembrane domains, and each receptor is coupled to a $G$ protein. One shows high specificity for ET-1 and the messenger RNA is widely distributed in the central nervous system, the heart and the lungs (ETA) (4). The other (5) is a non-selective receptor (ETB) but equally accepts all three endothelins, as well as sarafotoxins, and is coupled through a $\mathrm{G}$ protein to phospholipase $\mathrm{C}$, leading to transient increases in intracellular free $\mathrm{Ca}^{++}$. The messenger RNA for that receptor is not found in vascular smooth muscle. The discovery of three isopeptides of the endothelin family (7), ET-1, ET-2,ET-3, each possessing a diverse set of pharmacological activities of different potencies, suggests the existence of several different endothelin receptor subtypes $(6,7,8,9,10)$. Endothelins may elicit biological responses by various signal transduction mechanisms, including the $G$ protein - coupled activation of phospholipase $C$ and the activation of voltage-dependent $\mathrm{Ca}^{++}$channels $(11,12,13)$. Thus, different subtypes of the endothelin receptor may use different signal-transduction mechanisms.

Endothelin has also been shown to be present in the rat gastrointestinal tract (14) and high endothelin binding sites are shown to be present in muscle layer of the rat ileum, and shown to cause contraction of gastrointestinal smooth muscle (14). Endothelin like immunoreactivity was also localized to nerve bundles throughout the human colon and abundant $125 \mathrm{I}-\mathrm{ET}$-1 binding sites were found in both the myenteric and submucous plexuses, which are considered to be the main sites of

Address correspondence to: K.N. Bitar, Ph.D., Univ. of MI, 1510 E. MSRB I, Ann Arbor, MI 48109-0658 
neural regulation of the colon (15). We have investigated the presence of endothelin receptors on isolated smooth muscle cells of the rabbit rectosigmoid and have investigated their transmembrane signaling properties. Our data indicate that endothelin induces a direct sustained contraction of smooth muscle cells from the rabbit rectosigmoid similar to the contraction induced by exogenous protein kinase $C$. The early transient peak is independent of extracellular calcium, while the sustained phase of the contraction is totally dependent on calcium from extracellular sources. The transmembrane signalling of endothelin for each phase of contraction is through a specific but different GTP binding component that is Gia.

\section{Experimental procedures}

Isolation of Rabbit Rectosigmoid: The sphincteric region was identified as previously described (16). After anesthesia, the pelvic bone is exposed and opened and a $5 \mathrm{~cm}$ segment containing the terminal portion of the colon and rectum, including the anal sphincter, is measured and dissected free. The segment is opened with a midline incision along its anterior aspect, quickly rinsed, and pinned on a wax block at its in vivo length. The tissue is kept immersed in oxygenated Kreb's solution on ice. The junction of the rectal mucosa with the skin lining the outer portion of the canal is marked by sutures running through the whole thickness of the tissue; the external anal sphincter and the mucosa are removed by sharp dissection under a microscope, with care being taken not to disturb the sutures. Removal of the mucosa exposes the circular muscle layer; the circular fiber bundles are clearly visible. The internal anal sphincter, consisting of the distal most $3 \mathrm{~mm}$ of the circular muscle layer, ending at the junction of skin and mucosa, is discarded and a $5 \mathrm{~cm}$ aurad is removed and cells were isolated from this portion.

Dispersion of Smooth Muscle Cells: The cells are isolated as previously described (17). Tissue from the circular layer was incubated for two successive 60 -min periods at $31^{\circ} \mathrm{C}$ in $15 \mathrm{ml}$ of Krebsbicarbonate or HEPES buffer containing $0.1 \%$ collagenase $(150 \mathrm{U} / \mathrm{mg}$, Worthington CLS Type II, Freehold, NJ, USA) and $0.01 \%$ soybean trypsin inhibitor. At the end of the second enzymatic incubation period, the medium is filtered out through $500-\mu \mathrm{m}$ Nitex. The partly digested tissue left on the filter is washed four times with $50 \mathrm{ml}$ of collagenase-free buffer solution. The tissue is then transferred into $15 \mathrm{ml}$ of fresh buffer solution and incubated for $30 \mathrm{~min}$ to allow the cells to disperse spontaneously. Only the cells that dissociate spontaneously in enzyme-free solution are used for functional studies. Cells are counted in a hemocytometer and diluted as needed. Each rectosigmoid yields $4-6 \times 10^{6}$ cells.

Preparation of permeable smooth muscle cells : To test substances such as $\operatorname{Ins}(1,4,5) \mathrm{P}_{3}, \mathrm{PKC}$ or the $G$ protein antisera, which do not readily pass across the cell membrane, cells from the rectosigmoid are made permeable without affecting their overall function (18). The partly digested muscle tissue is washed with $50 \mathrm{ml}$ of a "cytosolic" enzyme-free medium (cytosolic buffer) with the following composition (millimolar): $\mathrm{NaCl}(20), \mathrm{KCl}(100), \mathrm{MgSO}_{4}(5.0), \mathrm{NaH}_{2} \mathrm{PO}_{4}(0.96)$, $\mathrm{NaHCO}_{3}(25.0)$, EGTA (1.0), $\mathrm{CaCl}_{2}(0.48)$. The medium contains $2 \%$ bovine serum albumin and is equilibrated with $5 \% \mathrm{O}_{2} / 95 \% \mathrm{CO}_{2}$ to maintain a $\mathrm{pH}$ of 7.2. Muscle cells are allowed to disperse spontaneously in this medium and are harvested by filtration on 500 um Nitex mesh. Isolated cells are permeabilized by incubation for $3 \mathrm{~min}$ in saponin $(75 \mu \mathrm{g} / \mathrm{ml})$. The cell suspension is then washed in cytosolic buffer. The cell suspension is filtered through 10- $\mu \mathrm{m}$ Nitex mesh; cells retained on the filter are washed free of saponin and resuspended in the cytosolic buffer containing antimycin $(10 \mu \mathrm{M})$, ATP $(1.5 \mathrm{mM})$, and an ATP-regenerating system consisting of creatinine phosphate $(5 \mathrm{mM})$ and creatinine phosphokinase (10 units $/ \mathrm{ml})$.

Permeabilized cells from the rectosigmoid were incubated with the $G$ protein antisera for one hour before the addition of the contractile agonists.

Measurement of Contraction: Muscle cells are usually examined within $30 \mathrm{~min}$ of dispersion. Aliquots consisting of $2.5 \times 10^{4}$ cells in $0.5 \mathrm{ml}$ of medium are added to $0.1 \mathrm{ml}$ of a solution containing the test agents. The agents are agonists, singly or in combination, or combinations of agonists and antagonists. In kinetic experiments the reaction is interrupted at various intervals (5 sec to $8 \mathrm{~min}$ ) by the addition of $0.1 \mathrm{ml}$ of acrolein at a final concentration of $1 \%$. In experiments where concentration-response characteristics are examined, the reaction is interrupted at the time of peak contractile response. Individual cell length is measured by computerized image micrometry. The 
average length of cells in the control state or after addition of test agents is obtained from 50 cells encountered randomly in successive microscopic fields. The contractile response is defined as the decrease in the average length of the $\mathbf{5 0}$ cells and is expressed as the absolute change or the percent change from control length (17).

G-protein antisera: G-protein antisera were utilized to test the involvement of specific $\mathrm{G} \alpha$ subunits in the signal transduction pathway of endothelin induced contraction. Antisera generated against short peptide sequences of $G \alpha$ subunits were obtained from DuPont NEN (Boston, MA). The antibodies have been shown to have the following specificities: $\mathrm{RM} / 1$ : binds to Gsa alone (19), EC/2: binds $\mathrm{Gi}_{3}>\mathrm{Go}_{\gg}>\mathrm{Gi}_{1}=\mathrm{Gi}_{2}$, AS $/ 7$ : binds $\mathrm{Gi}_{1}=\mathrm{Gi}_{2} \gg \mathrm{Gi}_{3}$, not to $\mathrm{Go}(20)$ (also transducin), GC/2: binds Go only (21). After resuspension in cytosol-like buffer, the cells were preincubated with the antibodies at a final dilution of 1:100 for $60 \mathrm{~min}$. At the end of the $60 \mathrm{~min}$., the same procedure was used as described before except smaller volumes were used due to the scarcity of the antibody. Aliquots of $0.1 \mathrm{ml}$ cells were used and all the other volumes were reduced accordingly.

Materials: Collagenase (CLS type II) was obtained from Wortington. Endothlelin-1 was obtained from Peninsula Laboratories (Belmont, CA). All other materials were obtained from Sigma (St. Louis, MO).

\section{Results}

Endothelin induced contraction of smooth muscle cells from the rectosigmoid: The response to endothelin ET-1 was concentration-dependent (Fig. 1). A threshold response was attained at $10^{-10} \mathrm{M}$, a half-maximal response was observed at $10^{-8} \mathrm{M}$. The response observed at $10^{-6} \mathrm{M}$ was not significantly different from the maximal response to acetylcholine $(35.7 \pm 1.2 \%$ versus $36.08 \pm$ $2.42 \%$ decrease in cell length from control). The kinetics of contraction of rectosigmoid cells in response to endothelin is shown in Fig. 2. Endothelin-induced contraction peaked at 60 seconds $36.08 \pm 2.42 \%$ and was sustained for up to 8 minutes (Fig. $2 \mathrm{~A}$ ). In the absence of calcium from the extracellular medium (OCa ${ }^{++} / 2 \mathrm{mM}$ EGTA), the kinetics of the contractile response to endothelin was

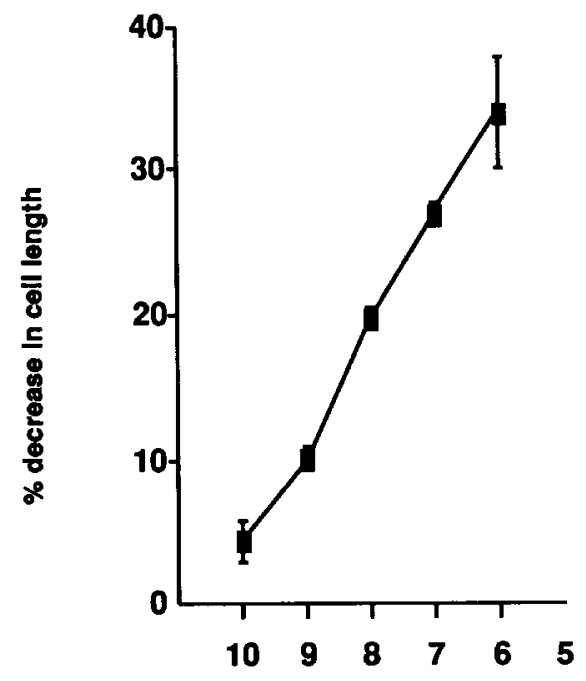

$(-) \log M$

Figure 1

The response of smooth muscle cells from the rectosigmoid of the rabbit. Smooth muscle cells were incubated with the indicated concentration of endothelin ET-1 for 30 seconds. The data are shown as mean \pm SEM of 3 experiments.

altered. The sustained contractile response observed in normal buffer was changed to a transient 
response, where the initial peak response was followed by a time dependent decline (Fig. 2B). The response is similar to the contraction induced by other peptides like substance P or CCK $(22,23)$, that do exhibit transient responses indicating that the maintenance of the sustained contraction is totally dependent upon influx of calcium from extracellular sources.

Effect of preincubation with antisera to G-proteins: Permeabilization of rectosigmoid cells with saponin and resuspension in a cytosol-like medium had no effect on cell length in the resting state (intact cells, $62.3 \pm 2.2 \mu \mathrm{m}$; permeabilized cells, $61.3 \pm 3.0 \mu \mathrm{m}$ (mean \pm S.E.)). Intact and permeabilized cells contracted identically in response to endothelin $10^{-6} \mathrm{M}(36.2 \pm 3.0$ versus $35.6 \pm$ $2.1 \%$ decrease in cell length from control) (Fig. 3).

Preincubation of permeabilized cells with the antisera RM/1(Gs $\alpha$ ) or GC/2 (Go) had no effect on the contractile response to endothelin (Fig. 3) indicating that the contractile response induced by endothelin was not affected by the preincubation technique. Preincubation with antiserum EC/2 $\left(\mathrm{Gi}_{3} \alpha\right)$ resulted in a significant inhibition of contraction at $30 \mathrm{sec}$, but no inhibition of contraction at 2-4 minutes implying that $\mathrm{Gi}_{3}$ subunit mediates the initial transient response induced by endothelin. Preincubation with the antiserum $\mathrm{AS} / 7\left(\mathrm{Gi}_{1-2} \alpha\right)$ did not affect the transient contraction observed at $30 \mathrm{sec}$, but significantly inhibited the sustained response at 2 and $4 \mathrm{~min}$, implying that a $\mathrm{Gi}_{1}$ or $\mathrm{Gi}_{2} \alpha$ subunit mediates the sustained contraction.

As mentioned earlier, no inhibition of contraction was seen when antisera specific for Go (GC) or Gs (RM) were utilized, thus Go and Gs do not appear to be involved in endothelin induced contraction.

A.

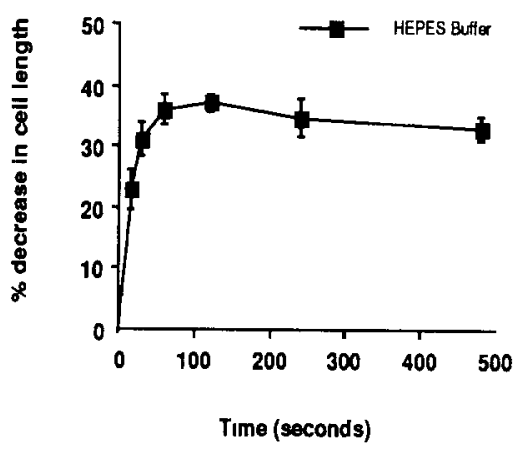

B.

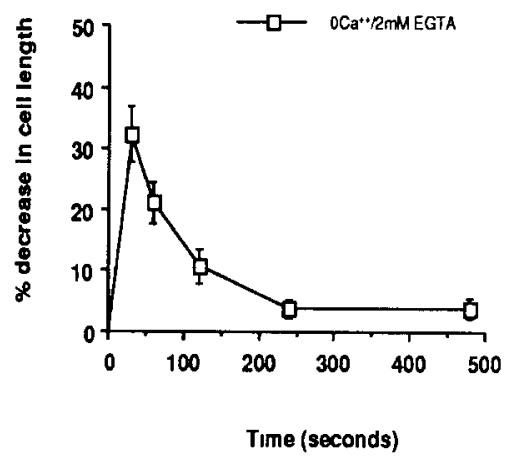

\section{Figure 2}

Smooth muscle cells were incubated with endothelin $\left(10^{-6} \mathrm{M}\right)$ for the indicated time. Endothelin induced contraction in normal Hepes buffer (Panel A) peaks and remains elevated for up to 8 minutes later. In the absence of $\mathrm{Ca}^{++}$in the medium $(0 \mathrm{Ca} / 2 \mathrm{mM}$ EGTA) (Panel B), endothelin induced contraction peaks at 30 seconds and decreased in a time dependent manner. Data are expressed as mean \pm SEM of 3 experiments.

\section{Discussion}

Endothelin has been shown to be present in the rat and human gastrointestinal tract $(14,15)$. High endothelin binding sites were shown to be present in muscle layer of the rat ileum. Our data indicate the presence of high affinity receptors for endothelin on isolated circular smooth muscle cells from the rabbit rectosigmoid. The higher efficacy observed in the rat colon vs the rabbit colon could be due to a species difference.

The vasoconstrictor effects of ET-1 are long-lasting. In gastrointestinal smooth muscle, in the presence of extracellular calcium, endothelin induced prolonged contraction while in the absence of 
extracellular calcium contraction was transient. Thus the response consists of two phases, an initial rapid phase which is independent of extracellular calcium and a slower prolonged phase which requires extracellular calcium. These two phases appear to correlate with the involvement of different G-proteins. $\mathrm{A} \mathrm{Gi}_{3}$-like protein appears to be required for the initial rapid transient phase of contraction and $\mathrm{Gi}_{1}$ or $\mathrm{Gi}_{2}$-like protein is required for the prolonged phase.

Control

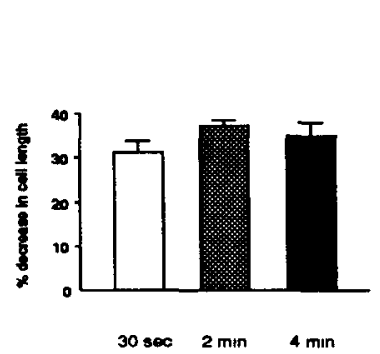

Preincubation with $\mathbf{G}$ protein antibody

$\mathbf{G s \alpha}$

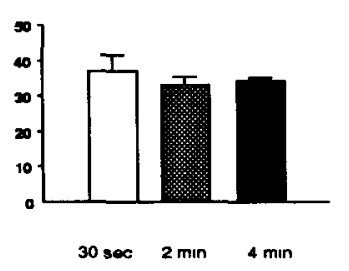

$\mathrm{GI}_{3} \alpha$

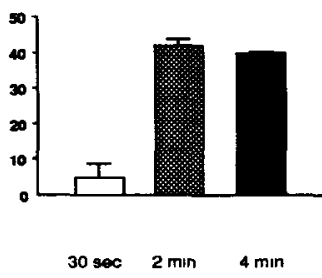

Goo

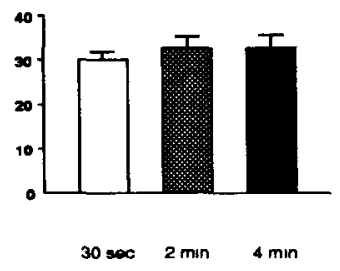

$\mathbf{G l}_{1-2} \alpha$

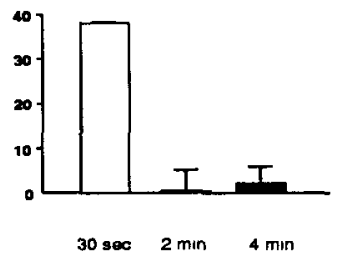

Figure 3

Permeabilization of rectosigmoid cells with saponin and resuspension in a cytosollike medium had no effect on cell length in the resting state. Intact and permeabilized cells contracted identically in response to endothelin $\left(10^{-6} \mathrm{M}\right)$. Permeabilized cells from the rectosigmoid were incubated with the antiserum for one hour before the addition of the contractile agonists. When saponified cells were incubated with the $G$ protein antiserum to Gs $\alpha$ or Goo, there was no effect on the contraction induced by endothelin. Preincubation with antiserum EC/2 $\left(\mathrm{Gi}_{3} \alpha\right)$ resulted in a significant inhibition of contraction at $30 \mathrm{sec}$, but no inhibition of contraction at 2-4 minutes. Preincubation with the antiserum AS/7 $\left(\mathrm{Gi}_{1-2} \alpha\right)$ did not affect the transient contraction observed at $30 \mathrm{sec}$, but significantly inhibited the sustained response at 2 and $4 \mathrm{~min}$. Data are expressed as mean \pm SEM of 3 experiments.

Endothelin was originally identified as a potent vasoconstrictor, but has later been shown to have a wide variety of biological activities on nonvascular tissues, including neurotransmission $(24,25)$. Endothelin has been shown to be a neuropeptide in the human intestine with binding sites on neural plexuses (15), suggesting a role in the modulation of intestinal motility as a candidate autocrine neuromodulator. Two distinct receptors for endothelin have been described. Those receptors probably serve different functions. There is a possibility that ET-1 activates the two subtypes of receptors which then couple specifically to the two G-proteins. Although both receptors may couple to both $\mathrm{G}$-proteins mediating the two phases of contraction. In either case the data demonstrates that each phase of the response is linked to a distinct G-protein.

We propose a model whereby signal transduction by endothelin causes contraction of gastrointestinal smooth muscle by activating two different $\mathrm{G}$-proteins which are coupled to distinct intracellular pathways: 1) $\mathrm{Gi}_{3}$ activating a phospholipase $\mathrm{C}$ resulting in $\mathrm{PtdIns}(4,5) \mathrm{P}_{2}$ hydrolysis and the formation of Ins- $(1,4,5) \mathrm{P}_{3}$ and 1,2-diacylglycerol. Ins-(1,4,5) $\mathrm{P}_{3}$ releases $\mathrm{Ca}^{++}$from stores inducing the formation of a $\mathrm{Ca}^{++}$-calmodulin complex, resulting in myosin light chain 
phosphorylation and thus the initial phase of the contraction; and 2) a $\mathrm{Gi}_{1}-\mathrm{Gi}_{2}$ activating $\mathrm{PKC}$ in the presence of 1,2-diacylglycerol and $\mathrm{Ca}^{++}$, resulting in the phosphorylation of other regulatory proteins (26) and thus inducing a calmodulin-independent (18) sustained contraction.

\section{Acknowledgements}

This work was supported by the National Institutes of Health Grant DK42876. We would also like to thank Colleen Croxall for her help in preparing this manuscript.

\section{References}

1. M. YANAGISAWA, H. KURIHARA, S. KIMURA, Y. TOMOBE, M. KOBAYASHI, Y. MITSUI, Y. YAZAKI, K. GOTO \& T. MASAKI. Nature 332 411-415 (1988).

2. N. TAKUWA, Y. TAKUWA, M. YANAGISAWA, K. YAMASHITA \& T. MASAKI. J. Biol. Chem. 264 7856-7861 (1989).

3. M. YANAGISAWA \& T. MASAKI. Trends Pharmacol. Sci. 10 374-378 (1989).

4. H. ARAI, S. HORI, I. ARAMORI, H. OHDUBO \& S. NAKANISHI. Nature 348 730-732 (1990).

5. T. SAKURAI, M. YANAGISAWA, Y. TAKUWA, H. MIYAZAKI, S. KIMURA, K. GOTO \& T. MASAKI. Nature 348 732-735 (1990).

6. A. INOUE, M. YANAGISAWA, S. KIMURA, Y. KASUYA, T. MIYAUCHI, K. GOTO \& T. MASAKI. Proc. Natl. Acad. Sci, USA 86 2863-2867 (1989).

7. Y. MASUDA, H. MIYAZAKI, M. KONDOH, H. WATANABE, M. YANAGISAWA, T. MASAKI \& K. MURAKAMI. FEBS Lett. 257 208-210 (1989).

8. Y. KLOOG, D. BOUSSO-MITTLER, A. BDOLAH \& M. SOKOLOVSKY. FEBS Lett. 253 199-202 (1989).

9. C. MAGGI, S. GUILIANI, R. PATACCHINI, P. SANTICHIOLI, A. GIACHETTI \& A. MELI. Eur. J. Pharmacol. 176 1-9 (1990).

10. T. WARNER, G. DENUCCI \& J. VANE. Eur J. Pharmacol. 159 325-326 (1989).

11. Y. KASUYA, Y. TAKUWA, M. YANAGISAWA, S. KIMURA, K. GOTO \& T. MASAKI Biochem. Biophys. Res. Commun. 161 1049-1055 (1989).

12. Y. TAKUWA, Y. KASUYA, N. TAKUWA, M. KUDO, M. YANAGISAWA, K. GOTO, T. MASAKI \& K. YAMASHITA. J. Clin. Invest. 85 653-658 (1990).

13. T. RESINK, T. SCOTT-BURDEN \& F. BUHLER. Eur. J. Biochem. 189 415-421 (1990).

14. K. TAKAHASHI, P. JONES, S. KANSE, H. LAM, R. SPOKES, M. GHATEI \& S. BLOOM. Gastroenterology 99 1660-1667 (1990).

15. H. INAGAKI, A.E. BISHOP, C. ESCRIG, J. WHARTON, T.G. ALLEN-MERSH, \& J.M. POLAK. Gastroenterology. 101 47-54 (1991).

16. P. BIANCANI, J. WALSH \& J. BEHAR. Gastroenterology 89 867-874 (1985).

17. K.N. BITAR, P. BRADFORD, J.W. PUTNEY \& G.M. MAKHLOUF. J. Biol. Chem. 261 16591-16596 (1986).

18. K.N. BITAR, C. HILLEMEIER, P. BIANCANI \& K.J. BALAZOVICH. Am. J. Physiol 260 G537-G542 (1991).

19. W.F. SIMONDS, P.K. GOLDSMITH, C.J. WOODARD, C.G. UNSON \& A.M. SPEIGEL. FEBS Lett. 249 189-194 (1989).

20. W. SIMONDS, P. GOLDSMITH, J. CODINA, C. UNSON \& A. SPIEGEL. Proc. Natl. Acad. Sci. USA 86 7809-7813 (1989).

21. P. GOLDSMITH, P.S. BACKLUND, K. ROSSITER, A. CARTER, G. MILLIGAN, C. UNSON \& A. SPIEGEL. Biochemistry 27 7085-7090 (1988).

22. K.N. BITAR \& G. MAKHLOUF. Am. J. Physiol. 193 G400-G407 (1982).

23. K.N. BITAR, C. HILLEMEIER \& P. BIANCANI. Life Sciences 47 2429-2434 (1990).

24. T. YOSHIZAWA, S. KIMURA, I. KANAZAWA, Y. UCHIYAMA, M. YANAGISAWA \& T. MASAKI. Neurosci Lett. 102 179-184 (1989).

25. M.W. MACCUMBER, C.A. ROSS \& S.H. SNYDER. Proc Natl. Acad. Sci USA 87 2359-2363 (1990).

26. L.P. ADAM, L. MILIO, B. BRENGLE \& D.R. HATHAWAY. J. Mol. Cell Cardiol. 22 1017-1023 (1990). 